\title{
Housing Privatization in Transition Countries: Institutional Features and Outcomes
}

\section{Hana M. Broulíková and Josef Montag ${ }^{1}$}

\begin{abstract}
We provide an overview of housing privatization policies and outcomes in transition economies. Our primary aim is to collect and systematize key information concerning the institutional features of housing privatization in individual countries: we identify the initial conditions, the timeframe of housing privatization and its culmination, the extent of housing privatization, who decided about its terms and conditions, who was entitled to privatize the housing, and at what price. Furthermore, using micro-data covering all transition countries, we present new estimates of the extent of housing privatization, its dynamics during the second half of the 2000s, and the resulting housing tenure structure.
\end{abstract}

Keywords: Housing privatization, homeownership, economic transition, postcommunist economies

JEL Classification: P3, R31, P14

Received: 7 June 2019 / Accepted: 25 February 2020 / Sent for Publication: XX March 2020

\section{Introduction}

In the aftermath of the World War II, European countries exhibited a general pattern of expanding the welfare state. This included the recognition of the government's responsibility for the reconstruction of the housing stock and solving the post-war shortage, eventually leading to an expansion of the public housing sector. In the 1970s, however, increasing national debts, together with an ideological turn to the right, resulted in a reversal of these ideas in favor of scaling the public provision of affordable housing down (Scanlon and Whitehead, 2008). Starting in 1980 in the United Kingdom, the Thatcher government launched widespread privatization of public housing stock that gradually spilled across Western European countries.

Following the example of Western Europe, housing privatization was an integral part of market reforms in former Eastern Bloc countries after the fall of communism (Clapham, 1996a). Transfers of public housing stock into private hands started early and proceeded

\footnotetext{
${ }^{1}$ Broulíková: Department of Health Sciences, Vrije Univeristeit Amsterdam, Amsterdam, Netherlands. Montag: Corresponding author. Department of Economics, Faculty of Law, Charles University, Address: nám Currieových 7, 11640 Praha 1, Czech Republic. Email: montagj@prf.cuni.cz.
}

(C) 2020 by the authors; licensee Review of Economic Perspectives / Národohospodářský obzor, Masaryk University, Faculty of Economics and Administration, Brno, Czech Republic. This article is an open access article distributed under the terms and conditions of the Creative Commons Attribution 3.0 license, Attribution - Non Commercial - No Derivatives. 
quickly. According to Hegedüs, Tosics, and Mayo (1996), almost one third of the public housing stock in transition countries of Central and Eastern Europe was privatized by 1995. Housing privatization was typically accompanied by the so-called restitution, which returned the property rights expropriated by the communist regimes to the rightful owners. Restitution of housing property, however, affected only an incomparably smaller part of the housing stock than privatization (Hegedüs, Tosics, et al., 1996; Lux, Cirman, and Sunega, 2017). Housing privatization is thus arguably the most significant transition-related determinant of the housing tenure structure in postcommunist countries.

The existing research on housing market reforms in post-communist countries is fragmented and often quite dated, limiting any systematic analysis of the development of housing during the transition era. The aim of this paper is to organize the stock of the currently available information and complement it by the empirical analysis of recent data to provide a wider perspective on housing privatization in transition economies. Specifically, we investigate the process and the outcomes of the housing privatization.

We collect and summarize the relevant information regarding the institutional details of housing privatization, focusing primarily on ten EU-member transition countries of Central and Eastern Europe (CEE) and Baltics. For each country, we identify: the timeframe during which privatization took place, its magnitude, the relevant decision level, the eligible privatizers, and the method of determining the sale price. We complement the picture by summarizing important country-specific details. Our findings are systematized in Table 1 . We complete the account with the rather scarce evidence on the countries of the former Soviet Union and the Balkans.

In addition, we provide estimates of the outcomes of housing privatization and its impact on the housing tenure structure. To that purpose, we use two waves, 2006 and 2010, of the Life in Transition Survey (LiTS) conducted by the European Bank for Reconstruction and Development. LiTS contains representative samples of households from all 29 former Eastern Bloc countries plus four Western European countries. Its important advantage is that it asks homeowner households how they acquired their ownership, with one option being privatization. LiTS is thus the most comprehensive dataset allowing us to obtain estimates of privatization rates across all transition economies.

The rest of the article is organized as follows: Section 2 provides brief background information on housing privatization in Western Europe. Section 3 summarizes the key background and institutional features of housing privatization in transition countries. Section 4 looks at the outcomes and recent dynamics. Section 5 concludes.

\section{Background: Housing Privatization in Western Europe}

In the 1980s, growing frustration over the welfare state politics coupled with an economic crisis led to a revival of laissez-faire ideas, favoring free markets, and limited government (Scanlon and Whitehead, 2008). This political turnover shifted the perception of housing and housing policy: instead of a social good, which needs to be provided by the government and subsidized from the taxpayer's pocket, housing was to be seen as a private good provided mainly by the market. 
As a consequence, housing policy of many Western European countries in this period was characterized by conversion of public housing stock into private property, typically through privatization to the sitting tenants (Tosics, 1987). Basic information on housing privatization in Western European countries covered by LiTS data are summarized at the bottom panel of Table 1.

The archetypal example of housing privatization is that of the United Kingdom. UK privatization started in 1980 when Margaret Thatcher's government introduced the "Right to Buy" policy as a part of the new Housing Act, with the main goal being to promote homeownership and cut public spending. Housing units were privatized under rather favorable conditions: initially, the discounts ranged between $33 \%$ and $50 \%$ of the market price, depending on the length of tenancy. Later, the terms became even more generous and the maximum discount amounted up to $70 \%$ (Whitehead, 1993). Further, the British government provided the privatizers with tax reliefs and loans up to $100 \%$ of the final price. As a result, about one quarter of the UK's public housing stock was privatized between 1980 and 1987 (Lundqvist, 1992).

In Italy, a policy to build and privatize social housing for low-income families was adopted already in 1949. However, the extent of privatization resulting from this initiative was negligible (Propersi, Mastrilli, and Gundes, 2012). A massive wave of privatization came much later in 1993, culminating in 1999. Specifically, the government offered housing units to employees of privatized companies at belowmarket rates, mainly in order to generate immediate income for the state budget (Bianchi and Bargelli, 2014). The privatizers were offered financial assistance in the form of tax reliefs and credit facilitations (Propersi, Mastrilli, and Gundes, 2012). More recently, municipal public housing also underwent privatization. As of 2010, almost $26 \%$ of LiTS respondents from Italy answered that they privatized their housing unit. And this number might have increased since then as a consequence of the 2014 Housing Plan, which introduced a general right for tenants to redeem the public dwelling after seven years of the tenancy (Bianchi and Bargelli, 2014).

The privatization of public companies played an important role in housing privatization also in former West Germany. Since late 1990s, the central government privatized housing owned by state-held companies, such as railways. Unlike in the UK and Italy, however, the privatizing entities consisted predominantly of institutional investors purchasing large bundles of dwellings. Municipalities also privatized some of their housing stock and were encouraged by the federal government to sell directly to sitting tenants. However, most of the sales went to the hands of institutional investors (Scanlon and Whitehead, 2008). Consequently, the homeownership rate in West Germany increased rather slightly from $41.7 \%$ in 1993 to $48.8 \%$ in 2010 (Cornelius and Rzeznik, 2014).

\section{Housing Privatization in Transition Countries}

This section overviews the main institutional features pertaining to housing privatization in ten EU-member transition countries of Central and Eastern Europe and the Baltics: the Czech Republic, the former East Germany, Estonia, Hungary, Latvia, Lithuania, Poland, Romania, Slovakia, and Slovenia. The core findings for each country are systematized in Table 1. The information available on housing privatization in the 
former Soviet Union (FSU) and Balkan countries is patchier and we discuss it where relevant.

\section{Pre-reform Public Housing Stock, the Extent, and Timing of Privatization}

During communism, private housing markets were virtually non-existent, all rental housing stock was publicly owned and rental units were allocated by public authorities on a permanent basis. Gebhardt (2013) even argues that in this setting, there was no practical difference between owning and renting. In this environment, people would often build their housing themselves, either as single-family dwellings or organized into housing cooperatives. They did so for pragmatic reasons: shortage of housing units and the subprime quality of the public housing stock (Clapham, 1996). As a result, a significant part of the housing stock in the CEE and Balkan countries was held privately and the share of public housing oscillated around 30\% in these two regions. However, the specific policies and the resulting tenancy structure differed significantly between the CEE countries, the Baltics, the FSU, and the Balkans.

The initial share of public housing stock is an important determinant of the extent of privatization. The estimates found in the literature, as well as the extent, and timing of housing privatization in individual countries are summarized in the first column of Table 1. We complement and update this information using the LiTS survey and compute the shares of privatized housing units on the overall housing stock as of $2006 .^{2}$ The results are reported in the first column of Table 2.

The extent of the initial public housing stock is likely to be related to the share of privatized housing units on the housing stock in two ways: First, it determines the number of housing units available for privatization. Second, countries with high initial public housing stock, particularly the FSU countries, seem to be the ones that privatized the most. This is corroborated by the results in Table 2. The share of privatized housing units on the housing stock often exceeds $30 \%$ in the FSU countries, whereas it tends to be less than $10 \%$ in the CEE countries and the Balkans.

More specifically, in the CEE countries, private homeownership was a relatively common form of tenancy during the Soviet era and sometimes even encouraged. In Czechoslovakia, Poland, and East Germany, housing cooperatives played an important role as a form of tenure. At the end of the communist era, a quarter of all dwelling units in Poland, $18 \%$ in Czechoslovakia, and $17 \%$ in East Germany were built and operated under this tenure form (Köhli and Kintrea, 1996; Kozlowski, 1996; Michalovic, 1996).

Housing privatization began soon after the fall of communism and, according to Hegedüs, Tosics, and Mayo (1996), almost one third of the public housing stock in Eastern and Central European post-communist countries was privatized by 1995 .

\footnotetext{
${ }^{2}$ We note that, to the extent some privatizers could have sold their housing units between privatization and the survey year, the results may understate the actual shares. However, housing markets in transition countries were still relatively underdeveloped, particularly in terms of financing, and these countries generally exhibit low migration rates, which mitigates these concerns (Bloze, 2009, Stephens, Lux, and Sunega, 2015). Broulíková, Huber, Montag, and Sunega (2018), using LiTS data, report low share of mortgage-financed housing as of 2010 .
} 
Privatization culminated in most observed countries around the year 2000. In the Czech Republic, a half of the public housing stock was sold by 2002 (Lux, 2003).

In Hungary, a housing policy introduced in 1983, well before the fall of communism, facilitated private homeownership (Tosics, 1987). Consequently, Hungary had a significant share of privately owned homes already before housing privatization begun. Hungarian sitting tenants could buy their property from 1989 and since then the public rent sector decreased from $20 \%$ to $4 \%$ in 2003 (Tosics, 1987).

In Bulgaria, sitting tenants could buy their homes after two years of tenancy. As a result, the homeownership rate reached $86 \%$ in 1988, and by 1990 it was 91\% (Lux, 2003; Tsenkova, Georgiev, Motev, and Dimitrov, 1996). In Romania, homeownership reached $75 \%$ in 1980 (Palacin and Shelburne, 2005). Romania privatized almost the entire public housing stock by 1999 (Dübel et al., 2006, Lux, 2003).

Balkan countries preserved their high pre-communism homeownership rates due to the so-called self-management model of socialism in former Yugoslavia, which was somewhat less centralized and created a complex network of institutions assuming many state responsibilities. Large companies often provided their employees with housing for rent as well as home loans (Mandič and Clapham, 1996; Mandič, 1996). In Croatia, 76\% of community flats were privatized by the end of 1997 (Tepus, 2005).

By contrast, FSU countries had very high shares of public housing on the housing stock, a result of housing policies restricting other forms of tenancy. As a consequence, the share of public housing stock amounted to $60 \%$ in Estonia and $70 \%$ in Latvia, and it was similar or higher than the other FSU countries (Struyk 1996; Tsenkova and Turner 2004). Estonia privatized almost its entire public housing stock by 2001 (Kask, Klettenberg, and Lembit, 2005; Lux, 2003). In Latvia, ownership titles to individual apartments were only changed in the official registry once the entire building was privatized, and the process was still ongoing in 2005 (Osa, 2005).

In Russia, the privatization process began already in 1988. The initial renters' response was very limited because they were enjoying strong tenancy rights and feared unbearable maintenance bills; as a result, only less than one percent of the eligible housing was privatized in 1990 (Berezin et al., 1996; Plotnikova, 2009). The subsequent restriction of tenancy rights and the introduction of free transfer of housing property finally accelerated the process, which was still incomplete in 2006 and only came to conclusion in 2013 (Attwood, 2012, Dübel et al., 2006). The process in Ukraine was faster, $72 \%$ of the public housing stock having been transferred immediately in the early 1990s (Tsenkova and Turner, 2004).

\section{Eligible Privatizers and the Selling Price}

The available information about eligible privatizers in individual countries is summarized in the second column of Table 1. As already mentioned, the eligible privatizers were generally the sitting tenants, either individual households or legal persons representing properties. In the Czech Republic, Poland, and Slovakia, the actual privatizing entities were typically cooperatives established for the purpose of privatization by the tenants living in privatized houses. This may be explained by the fact that the privatization-related transaction costs borne by the municipalities were 
lower when dealing with coops as opposed to individual households. In addition, privatization to individual tenants would result in mixed ownership whereas some apartments are owned by individuals and others by the municipality, leading to increased running costs (Sýkora, 2003). Although other forms of privatization were possible, using 1991 and 2011 census data, Mikula and Montag (2019) report that tenant coops were the actual privatizers in at least $84 \%$ privatized properties in Brno. The only significant exception from the rule was former East Germany, where, similarly as in the former West Germany, a large part of the privatized housing stock was sold to institutional investors (Scanlon and Whitehead, 2008).

Another important parameter of housing privatization was the selling price, the available information about which is summarized in the third column of Table 1. Generally, the transition governments were motivated to swiftly privatize their public housing stocks in order to avoid high maintenance costs and to introduce market principles into the highly inefficient housing sector (Clapham and Kintrea, 1996a). Although a giveaway or low-price strategy was employed in most cases (Clapham and Kintrea, 1996b), there were some differences with respect to the actual prices and the methods with which they were determined.

Since free housing markets did not exist during the Soviet era, the values of properties usually needed to be established administratively. The value was typically derived from the construction year, accounting for major repairs, and sometimes also location or other characteristics. In Slovenia, nevertheless, a second-hand housing market operated even during the communist era and, consequently, market prices were known. The data shows that an average apartment was privatized for $20 \%$ of its market value (Mandič, 1996). This observation generally corresponds with estimates of privatization prices for other countries.

In the CEE countries, housing units were generally sold at prices well below their market value, incorporating explicit discounts. To illustrate, in Hungary, sitting tenants could buy their property for $10 \%-15 \%$ of the market price (Lux, 2003). In Poland, the discount was typically over $80 \%$ (Skiba, 2005) and could amount up to $95 \%$ of the market value (Lis and Zwierzchlewski, 2015). In Slovakia and Slovenia, the discount started at $30 \%$ and could increase up to $80 \%$ and 60\%, respectively (Lux, 2003; Sendi, 1995).

Due to the decentralized nature of housing privatization in the Czech Republic, systematic evidence on prices is lacking. In one town (Sokolov), Sykora (2003) reports discounts of $80 \%$. In Brno, the second largest city in the country, the discounts were between 35 or $65 \%$, depending on whether the purchase was on credit (without interest being charged) or the price was paid upfront (see Mikula and Montag, 2019, for details about housing privatization in Brno). However, these were discounts from the administratively set valuations of privatized properties, which were likely to be set low to begin with. ${ }^{3}$

\footnotetext{
${ }^{3}$ A personal experience of one of the authors (Montag) may provide further insight into the price setting and property transfer process. The apartment building in Prague, housing about 17 families, was privatized in
} 
The only transition country adopting a high-price sales strategy was the former East Germany. The aim of the Federal Government was to firstly renovate the existing stock in order to protect privatizers from unforeseeable financial burdens (Clapham and Kintrea, 1996b; Köhli and Kintrea, 1996). Although the selling prices reflected these investments, they still did not reach the market value of the property (Scanlon and Whitehead, 2008).

On top of the discounts, governments often provided financial assistance to the privatizing tenants in order to facilitate privatization. For instance, Romania offered a 25 -year loan with a 4\% interest rate (Lux, 2003). Hungarian tenants could repay the property price in 35 years with a $3 \%$ interest rate (Hegedüs, Mark, Sárkány, and Tosics, 1996).

An event with a major effect on the privatization processes in the Balkans was the collapse of the Yugoslav federal state and the ensuing ethnic war. During the initial privatization period, between 1990 and 1992, the most desirable property was privatized for $30 \%$ of its estimated market price mainly by elite communist politicians who managed to stay in leading positions. Majority of the population faced a war-related income decrease and only the hyperinflation in 1993 made privatization attractive (Petrović, 2001).

By contrast, public housing units in the FSU countries were most often offered to the sitting tenants for free. This is particularly well documented for Ukraine and Russia (Attwood, 2012; Berezin, Kaganova, Kosareva, Pritkov, and Struyk, 1996; Tsenkova and Turner, 2004). The Baltic FSU countries of Estonia, Latvia, and Lithuania employed a method of privatization vouchers that also resulted in an almost or entirely free transfer. In Estonia, three hundred pieces of "public capital voucher" (EVP) were awarded for each working year and their value approximately equated to the price of one squared meter of a virtual standard unit in nine-story prefabricated panel building. The price of a housing unit was set as a difference between the values of a privatized and the standard unit (Lux, 2003). Consequently, a person working for 40 years could buy a two-room apartment. In fact, most privatizers could buy their housing units with no additional payment, just using their EVPs. In Latvia, vouchers were distributed per the length of the residency in Latvia during the period 1945-1992 or, alternatively, perforced exile years. One Latvian voucher equaled to half a squared meter of residential space (Kursis, 1999). Both Estonian and Latvian vouchers were tradable. However, trading was not allowed in the neighboring Lithuania, where the vouchers (Investicnis Cekis, IC) were distributed according to the age of the recipient, and where the price of a unit was calculated according to its construction characteristics and location. ICs could cover only up to $80 \%$ of the price; the rest needed to be paid in cash (Kursis, 1999; Milstead and Miles, 2011).

1996 with an overall discount of $70 \%$, relative to the administrative price estimate, which itself was likely to be significantly below the market value. Moreover, only $20 \%$ of the price had to be paid up front. The remainder was paid over the following 10 years, with no interest charged. The cooperative, established by the tenants for the purpose of the privatization, became a full owner after the whole price was repaid in 2006 . About ten years later, the cooperative transformed into an association of owners and individual household became direct owners of their units. 


\section{Decision Level}

Housing privatization can be further characterized by the level of centralization at which it was implemented. The available information on this is summarized in the fourth column of Table 1. In some countries, tenants were given the right to buy. For instance, in Slovakia, the houses eligible for privatization as well as the terms were specified at the central government level. If more than half of tenants of a privatization-eligible apartment building agreed, municipalities were obliged to privatize it within two years (Zapletalova, Antalikova, and Smatanova, 2003). In most other CEE as well as FSU countries, privatization was also implemented at the central government level; the entitled privatizers - mostly sitting tenants - as well as the conditions, were usually specified centrally although local authorities often administered the process according to these directives.

Exceptions from the rule are the Czech Republic, Poland, and East Germany. In these countries, municipalities were the owners of most public housing and privatization was fully in their discretion (Grabmüllerová, 2005). In the Czech Republic, for example, the ownership of the public housing stock was transferred to municipalities already in 1991, and they could set their own housing policy. The tenants did not have the right to buy and it was up to the municipalities to decide the extent and terms of privatization. In East Germany, municipalities were centrally ordered to sell at least $15 \%$ of public housing, the remainder having been left to their own discretion (Köhli and Kintrea, 1996). Following the practice of federal sales in West Germany, some property was sold to institutional investors rather than to the sitting tenants (Scanlon and Whitehead, 2008). ${ }^{4}$

\section{Privatization Outcomes and Recent Dynamics}

\section{Data}

We use the 2006 and 2010 LiTS survey to measure the extent and recent dynamics of housing privatization in transition countries. ${ }^{5}$ The survey was conducted in 28 transition countries in Central and Eastern Europe and the former Soviet Union, plus five Western European "comparator" countries (Germany, France, Italy, Sweden, and the United Kingdom), as well as Mongolia and Turkey. ${ }^{6}$

\footnotetext{
${ }^{4}$ Apart from that, tenants of Czech and Polish housing cooperatives (but not tenants in publicly-owned dwellings) were centrally awarded a right to buy their housing units. These cooperatives later transformed into owners' associations with owners gaining full property rights to their units (Lis and Zwierzchlewski; Lux, 2003). It is noteworthy that owners of units in Polish coops gained also the right to mortgage the property (Kozlowski, 1996). Polish cooperative title holders were given the right to transform their existing tenures to ownership only in 2004 (Zawislak, 2002).

${ }^{5}$ For details and access to the LiTS data see the http://www.ebrd.com/what-we-do/economic-research-anddata/data/lits.html (last accessed on January 15, 2020).

${ }^{6}$ The former East Germany and Kosovo were not included in the 2006 wave.
} 
For most countries, 50 Primary Sampling Units (PSUs) were randomly selected from the local electoral units, with the probability of selection proportional to PSU size. For Russia, Ukraine, Uzbekistan, Serbia, Poland, and the UK, the sample consists of 75 PSUs. Subsequently, 20 households were randomly chosen within each PSU for interviews. For each country, the database therefore contains a sample of about 1,000 or 1,500 households, depending on the PSU size. Interviewers had to visit each selected household at least three times before replacing it with another one. In $79 \%$ of cases, however, the interviews were completed on the first visit. The questionnaire consists of two parts: a household roster and expenses form, answered by the head of the household, and the main part answered by the principal respondent, a randomly selected member of the household above the age of 18 . In $61 \%$ of the cases, the household head and the principal respondent were the same person, while in the remainder two different interviews were conducted in the same household. ${ }^{7}$

For the subsequent analysis, we drop Mongolia and Turkey, as they are out of the geographic scope of this paper. Other than that, we use the data as is in order to maintain its representativeness.

\section{Privatization measures and statistical tests}

Our main outcome of interest is the extent of housing privatization, measured by the share of households living in privatized housing units, and for brevity we refer to this measure as "privatization rate." As mentioned in footnote 2, this indicator may underestimate the share of people who live in privatized dwellings since some of these dwellings could have already been sold by the privatizers or inherited (a possible answer to the ownership source question in LiTS data). On the other hand, in most transition countries, financial institutions to facilitate the market exchange of property have evolved only gradually during the transition, rendering housing markets.

We analyze the within-country dynamics of privatization rates between 2006 and 2010 using the exact test for comparing medians (Shlag, 2015). This test is more conservative (i.e. less powerful) than, for instance, the $t$-test, but does not require us to assume normal distribution (which in our case would clearly be violated) and is mathematically exact in terms of Type I error rate under the null (see Shlag, 2015, for more details).

\section{Results}

The estimates are reported in Table 2. The estimates of privatization rates and tests of their dynamics are reported in Table 2. Privatization rates vary widely between countries as well as across the larger geographic regions. CEE and Balkan countries are generally characterized by privatization rates below $10 \%$. In the FSU states, privatization rates are higher: Namely, the data shows that $30 \%$ of respondents in

\footnotetext{
${ }^{7}$ For more details about the surveying process and outcomes see www.ebrd.com/news/publications/specialreports/life-in-transition-survey-ii.html (last accessed on January 15, 2020).
} 
Lithuania, $38 \%$ in Estonia, and 51\% in Latvia live in a dwelling that they privatized. In Russia, the share of households living in privatized apartments amounts to $62 \%$.

A more recent dynamics of the housing markets in transition countries is also reported in Table 2. Specifically, the first two columns compare the privatization rates between the two survey waves in 2006 and 2010 and test their difference, using the exact test for comparing medians, which is reported in the third column.

For about half of the observed transition countries (Armenia, Azerbaijan, Belarus, Cosovo, Croatia, Czech Republic, Estonia, Hungary, Kyrgyzstan, Moldova, Romania, Serbia, and Ukraine) the privatization rates stayed relatively stable. This likely means that the main privatization waves were over by 2006 , consistent with the evidence from the existing literature discussed above, and that the new homeowners had not extensively sold their property until 2010.

In ten countries, Albania, Georgia, Latvia, Lithuania, Kazakhstan, Macedonia, Poland, Russia, Slovenia, and Tajikistan, the share of households reporting they live in a privatized unit increased between 2006 and 2010. The change was concentrated among the FSU countries (for example, +7.5 percentage points in Georgia, +9 p.p. in Kazakhstan, +13 p.p. in Latvia, and +14.5 p.p. in Russia). This means that the housing privatization was still ongoing during this timeframe. In Poland, Skiba (2005) reports ongoing privatization after the turn of the millenium, which is also consistent with our data.

An increasing privatization rate in Lithuania seems contradictory to the facts reported by Kursis (1999) and Housing and Urbanization Development Fund (2005). According to it, Lithuania experienced a rapid transfer of ownership, accomplishing $95 \%$ of possible flat privatization already by July 1995 . A possible reason behind this contradiction might lie in the fact that privatization of housing was followed by the privatization of enterprises (Housing, Urbanization, and Development Fund, 2005; Jurgaityte, 2002), which frequently includes also housing dwellings owned by the companies.

According to the LiTS data, privatization rates significantly decreased only in five countries between 2006 and 2010 (Bosnia and Herzegovina, Bulgaria, Montenegro, Slovakia, and Uzbekistan). This decrease is likely given by further developments in the housing market; namely, newly built housing stock during the timeframe and possible sales of privatized units by privatizers. ${ }^{8}$

\footnotetext{
${ }^{8}$ However, the estimated change from $21.6 \%$ to $2.3 \%$ in Slovakia is surprising as the CEE region generally did not experience privatization rates over 10\%. Dübel et al. (2006) discusses factors why the reported tenure structure might be biased. For instance, unclear ownership titles such as rental contracts conveying a purchase or cost-free privatization option that has not yet been exercised might cause confusion. In the case of Slovakia, it seems that the high privatization share of 2006 could lie in an inaccurately reported tenure type by people living in cooperative buildings.
} 


\section{Conclusion}

Housing privatization has significantly affected the tenure structure on both sides of the Iron Curtain. In Western Europe, abandoning public housing was motivated by an ideological turn to the right, and by the effort to decrease public spending by reducing the welfare state. In Eastern Europe, housing privatization was introduced one decade later, around 1990, as a part of the transition following the collapse of communism. Since then, housing privatization has shaped the housing-market structure and created a new class of homeowners in many European countries.

We have provided an overview of privatization strategies employed by individual countries and used this knowledge to offer some observations on the common patterns as well as differences between countries. As the housing privatization process in transition countries began more than two decades ago and mostly culminated in around 2000, we are already able to observe its results. Using the 2006 and 2010 LiTS surveys, the best available and most comprehensive micro data on housing in transition countries, we thus present new estimates of privatization extent and recent dynamics.

Arguably, privatization of public housing has had remarkable social impact. Although the exact estimates are not available, given the volumes of transferred property in individual countries, housing privatization could have well been the largest transfer of publicly owned property into private hands during the transition era. We believe that future research investigating the effects of housing privatization on a variety of economic outcomes may yield valuable insights into the role and value of homeownership in the economy generally and the effects of housing privatization specifically. This paper provides basic background information for such endeavors.

Acknowledgements: For helpful comments and suggestions, we thank Peter Huber and Petr Sunega.

Funding: Financial support from the Czech Science Foundation, grant no. 15-17810S, is gratefully acknowledged.

Disclosure statement: No conflict of interest was reported by the authors.

\section{References}

Attwood, L. (2012). Privatisation of housing in post-Soviet Russia: a new understanding of home? Europe-Asia Studies, 64(5), 903-928. DOI: 10.1080/09668136.2012.681243

Berezin, M., Kaganova, O., Kosareva, N., Pritkov, A., and Struyk, R. (1996). The Russian Federation. In D. Clapham, J. Hegedüs, K. Kintrea, I. Tosics, and H. Kay (Eds.), Housing Privatization in Eastern Europe (pp. 79-95). London: Greenwood Press.

Bianchi, R., and Bargelli, E. (2014). National Report for Italy. Retrieved from Clapham, D. (1996). Housing Privatization in Eastern Europe: Greenwood Publishing Group.

Bloze, G. (2009). Interregional Migration and Housing Structure in an East European Transition Country: A View of Lithuania 2001-2008. Baltic Journal of Economics 9, 47-66. DOI: 10.1080/1406099X.2009.10840461 
Broulíková, H., Huber, P., Montag, J., and Sunega, P. (2018). Homeownership, Mobility, and Unemployment. Evidence from Housing Privatisation. WIFO Working Papers 548. Vienna, Austria: Austrian Institute of Economic Research.

Clapham, D., and Kintrea, K. (1996a). Analyzing Housing Privatization. In D. Clapham, J. Hegedüs, K. Kintrea, I. Tosics, and H. Kay (Eds.), Housing Privatization in Eastern Europe (pp. 1-13). London: Greenwood Press.

Clapham, D., and Kintrea, K. (1996b). The Patterns of Housing Privatization in Eastern Europe. In D. Clapham, J. Hegedüs, K. Kintrea, I. Tosics, and H. Kay (Eds.), Housing Privatization in Eastern Europe (pp. 169-193). London: Greenwood Press.

Cornelius, J., and Rzeznik, J. (2014). National Report for Germany. Retrieved from Clapham, D. (1996). Housing Privatization in Eastern Europe: Greenwood Publishing Group.

Gebhardt, Georg. 2013. "Does Relationship Specific Investment Depend on Asset Ownership? Evidence from a Natural Experiment in the Housing Market." Journal of the European Economic Association 11, 201-227. DOI: 10.1111/j.15424774.2012.01106.x

Grabmüllerová, D. (2005). Housing Finance in Czech Republic. In S. Shinozaki (Ed.), Housing Finance Markets in Transition Economies: OECD Publishing.

Dübel, Hans-Joachim, W. Jan Brzeski, and Elen Hamilton. (2006). Rental Choice And Housing Policy Realignment In Transition: Post-Privatization Challenges In The Europe And Central Asia Region: World Bank.

Hegedüs, J., Mark, K., Sárkány, C., and Tosics, I. (1996). Hungary. In D. Clapham, J. Hegedüs, K. Kintrea, I. Tosics, and H. Kay (Eds.), Housing Privatization in Eastern Europe (pp. 57-77). London: Greenwood Press.

Hegedüs, J., Tosics, I., and Mayo, S. K. (1996). Transition of the housing sector in the east central European countries. Review of Urban and Regional Development Studies, $8(2), 101-136$.

Housing, Urbanization, and Development Fund. (2005). Housing Finance in Lithuania. In S. Shinozaki (Ed.), Housing Finance Markets in Transition Economies: OECD Publishing.

Jurgaityte, D. (2002). Framewors for the Housing Sector of Lithuania. In T. Yasui (Ed.), Housing Finance in Transition Economies: OECD Publishing.

Kask, J., Klettenberg, T., and Lembit, O. (2005). Housing Finance in Estonia. In S. Shinozaki (Ed.), Housing Finance Markets in Transition Economies: OECD Publishing.

Köhli, J., and Kintrea, K. (1996). The New Länder of Germany. In D. Clapham, J. Hegedüs, K. Kintrea, I. Tosics, and H. Kay (Eds.), Housing Privatization in Eastern Europe (pp. 41-55). London: Greenwood Press.

Kozlowski, E. (1996). Poland. In D. Clapham, J. Hegedüs, K. Kintrea, I. Tosics, and H. Kay (Eds.), Housing Privatization in Eastern Europe (pp. 119-134). London: Greenwood Press. 
Kursis, J. (1999). Housing privatisation in the Baltic states: Lund University, Housing Development and Management.

Lis, P., and Zwierzchlewski, S. (2015). Dilemmas of and Methods for Transforming State-Owned Enterprises and Public Housing Stock in Poland-An Attempt at Defining the Model of Privatization. American International Journal of Social Science, 4(2), 8088 .

Lundqvist, L. J. (1992). Dislodging the welfare state?: Housing and privatization in four European nations: Delft University Press.

Lux, M. (2003). Housing policy: an end or a new beginning? : Local Government and Public Service Reform Initiative/Open Society Institute.

Lux, M., Cirman, A., and Sunega, P. (2017). Housing restitution policies among postsocialist countries: explaining divergence. International Journal of Housing Policy, 17(1): 145-156. DOI: 10.1080/14616718.2016.1246602

Mandič, S., and Clapham, D. (1996). The meaning of home ownership in the transition from socialism: the example of Slovenia. Urban Studies, 33(1), 83-97. DOI: $\underline{10.1080 / 00420989650012130}$

Mandič, S. (1996). Slovenia. In D. Clapham, J. Hegedüs, K. Kintrea, I. Tosics, and H. Kay (Eds.), Housing Privatization in Eastern Europe (pp. 151-167). London: Greenwood Press.

Michalovic, P. (1996). Czechoslovakia. In D. Clapham, J. Hegedüs, K. Kintrea, I. Tosics, and H. Kay (Eds.), Housing Privatization in Eastern Europe (pp. 135-149). London: Greenwood Press.

Mikula, Š., Montag, J. (2019). Does homeownership hinder labor market activity? Evidence from housing privatization and restitution. MUNI ECON Working Paper no. 2019-06. Brno: Masaryk University. Available online at https://ssrn.com/abstract= 3392341.

Milstead, T. M., and Miles, R. (2011). DIY home improvements in a post-soviet housing market: A socio-spatial analysis of Vilnius, Lithuania. Housing Studies, 26(03), 403-421. DOI: $\underline{\text { 10.1080/02673037.2011.542099 }}$

Osa, I. (2005). Housing Finance in Latvia. In S. Shinozaki (Ed.), Housing Finance Markets in Transition Economies: OECD Publisher.

Palacin, J., and Shelburne, R. C. (2005). The private housing market in Eastern Europe and the CIS: United Nations Economic Commission for Europe Geneva.

Petrović, M. (2001). Post-socialist housing policy transformation in Yugoslavia and Belgrade. European Journal of Housing Policy, 1(2), 211-231. DOI: $\underline{10.1080 / 14616710110083434}$

Plotnikova, M. (2009). A Model of Housing Privatization Decision: the Case of Russia. under review in Housing Economics.

Propersi, A., Mastrilli, G., and Gundes, S. (2012). The Third Sector and Social Housing in Italy: case study of a profit and non-profit public private partnership. Paper 
presented at the "Democratization, Marketization, and the Third Sector" 10th International Conference of the International Society for Third Sector Research (ISTR), Siena, Italy.

Scanlon, K., and Whitehead, C. (Eds.). ( 2008). Social Housing in Europe II A review of policies and outcomes. London: London School of Economics and Political Science.

Sendi, R. (1995). Housing reform and housing conflict: the privatization and denationalization of public housing in the Republic of Slovenia in practice. International Journal of Urban and Regional Research, 19(3), 435-446. DOI: 10.1111/j.1468-2427.1995.tb00519.x

Shlag, K. (2015). Who gives Direction to Statistical Testing? Best Practice meets Mathematically Correct Tests. Working Paper, University of Vienna.

Skiba, K. (2005). Housing Finance in Poland. In S. Shinozaki (Ed.), Housing Finance Markets in Transition Economies: OECD Publishing.

Stephens, M., Lux, M., and Sunega, P. (2015) Post-Socialist Housing Systems in Europe: Housing Welfare Regimes by Default. Housing Studies 30, 1210-1234. DOI: $\underline{10.1080 / 02673037.2015 .1013090}$

Struyk, R. J. (1996). Housing privatization in the former Soviet bloc to 1995. Cities after socialism: Urban and regional change and conflict in post-socialist societies, 192213.

Sýkora, L. (2003.) Between the State and the Market: Local Government and Housingin the Czech Republic. In M. Lux (Ed.) Housing policy: an end or a new beginning? Open Society Institute, 51-116.

Tepus, M. M. (2005). Housing Finance in Croatia. In S. Shinozaki (Ed.), Housing Finance Markets in Transition Economies: OECD Publishing.

Tosics, I. (1987). Privatization in housing policy: the case of the Western countries and that of Hungary. International Journal of Urban and Regional Research, 11(1), 61-78. DOI: $10.1111 /$ j.1468-2427.1987.tb00035.x

Tsenkova, S., Georgiev, G., Motev, S., and Dimitrov, D. (1996). Bulgaria. In D. Clapham, J. Hegedüs, K. Kintrea, I. Tosics, and H. Kay (Eds.), Housing Privatization in Eastern Europe (pp. 98-117). London: Greenwood Press.

Tsenkova, S., and Turner, B. (2004). The future of social housing in Eastern Europe: Reforms in Latvia and Ukraine. European Journal of Housing Policy, 4(2), 133-149. DOI: $\underline{10.1080 / 1461671042000269001}$

Whitehead, C. M. (1993). Privatizing housing: an assessment of UK experience. Housing Policy Debate, 4(1), 101-139.

Zapletalova, J., Antalikova, M., and Smatanova, E. (2003). The Role of Selfgovernment in Housing Development in Slovakia. Housing Policy: an End or a New Beginning.

Zawislak, M. (2002). Housing Finance in Poland. In T. Yasui (Ed.), Housing Finance in Transition Economies: OECD Publishing. 


\section{Appendix}

Table 1: Overview of Privatization Policies

\begin{tabular}{|c|c|c|c|c|}
\hline $\begin{array}{c}\text { Period and } \\
\text { Pre-reform } \\
\text { Public Housing } \\
\text { Stock } \\
\end{array}$ & Privatizers & Prices & Decision Level & Other Details \\
\hline \multicolumn{5}{|c|}{ Transition countries } \\
\hline \multicolumn{5}{|l|}{ Czech Republic } \\
\hline $\begin{array}{l}\text { Since } 1992 . \\
\text { About one half } \\
\text { of public } \\
\text { housing stock } \\
\text { was privatized } \\
\text { by } 2002 . \\
\text { Prior to the } \\
\text { privatization } \\
38 \% \text { of the } \\
\text { rental units } \\
\text { were public, } \\
18 \% \text { were } \\
\text { housing } \\
\text { cooperatives. }\end{array}$ & $\begin{array}{l}\text { Legal } \\
\text { persons } \\
\text { representing } \\
\text { the sitting } \\
\text { tenants, } \\
\text { typically } \\
\text { coopera- } \\
\text { tives. } \\
\text { Since } 1994 \\
\text { also } \\
\text { individual } \\
\text { households. }\end{array}$ & $\begin{array}{l}\text { Various } \\
\text { discounts from } \\
\text { the market price } \\
\text { usually granted } \\
\text { by } \\
\text { municipalities. }\end{array}$ & $\begin{array}{l}\text { Municipalities } \\
\text { decided about the } \\
\text { privatization scale } \\
\text { and terms of most } \\
\text { public dwellings. } \\
\text { Centrally given } \\
\text { Right-to-Buy only } \\
\text { for existing coop } \\
\text { housing. }\end{array}$ & $\begin{array}{l}\text { Later, coops could } \\
\text { mutate into } \\
\text { owners' } \\
\text { associations, with } \\
\text { the owners } \\
\text { gaining full } \\
\text { property rights to } \\
\text { their unit. }\end{array}$ \\
\hline \multicolumn{5}{|l|}{ East Germany } \\
\hline $\begin{array}{l}\text { Since } 1993, \\
\text { culminating } \\
\text { between } 1993 \\
\text { and } 1999 . \\
\text { Prior to } \\
\text { privatization, } \\
25 \% \text { of } \\
\text { homeowners } \\
\text { In } 1990 \text { s and } \\
2000 \text { s } \\
\text { privatization to } \\
\text { institutional } \\
\text { investors. }\end{array}$ & $\begin{array}{l}\text { Sitting } \\
\text { tenants of } \\
\text { public } \\
\text { dwellings. } \\
\text { - Members of } \\
\text { housing } \\
\text { coopera- } \\
\text { tives. } \\
\text { - Institutional } \\
\text { investors. }\end{array}$ & $\begin{array}{l}\text { During the first } \\
\text { wave, the sale } \\
\text { prices were far } \\
\text { below market } \\
\text { prices. } \\
\text { Federal sales to } \\
\text { institutional } \\
\text { investors for } \\
\text { extremely low } \\
\text { prices. }\end{array}$ & $\begin{array}{l}\text { Municipalities } \\
\text { were centrally } \\
\text { ordered to sell at } \\
\text { least } 15 \% \text { of } \\
\text { public rental } \\
\text { housing and coops. } \\
\text { Local-level } \\
\text { decision for the } \\
\text { remainder of the } \\
\text { public housing } \\
\text { stock. }\end{array}$ & $\begin{array}{l}\text { Initially higher } \\
\text { involvement of } \\
\text { tenants and coop } \\
\text { members than in } \\
\text { West Germany. } \\
\text { Afterwards the } \\
\text { approach to } \\
\text { privatization } \\
\text { similar to West } \\
\text { Germany. }\end{array}$ \\
\hline \multicolumn{5}{|l|}{ Estonia } \\
\hline $\begin{array}{l}\text { 1993-2001. } \\
\text { About } 85-90 \% \\
\text { of the public } \\
\text { housing stock } \\
\text { was privatized. } \\
\text { Prior to the } \\
\text { privatization } \\
60 \% \text { of the } \\
\text { rental units } \\
\text { were public. }\end{array}$ & $\begin{array}{l}\text { Sitting } \\
\text { tenants. }\end{array}$ & $\begin{array}{l}\text { Public capital } \\
\text { vouchers } \\
\text { (EVPs) } \\
\text { distributed } \\
\text { according to } \\
\text { employment } \\
\text { length. } \\
\text { - Price set as a } \\
\text { difference } \\
\text { between the } \\
\text { respective unit } \\
\text { and a } \\
\text { "standard" } \\
\text { panel unit. } \\
\text { - Other discounts } \\
\text { applicable. }\end{array}$ & $\begin{array}{l}\text { - Central } \\
\text { Local authorities } \\
\text { could restrict } \\
\text { privatization - i.e. } \\
\text { to select dwellings } \\
\text { not available for } \\
\text { privatization - but } \\
\text { the pressure from } \\
\text { both the central } \\
\text { government and } \\
\text { tenants was strong } \\
\text { and this right was } \\
\text { seldom used. }\end{array}$ & $\begin{array}{l}\text { EVP awarded for } \\
\text { one working year } \\
\text { was appro. equal } \\
\text { to the price of } 1 \\
\mathrm{~m}^{2} \text {. Consequently, } \\
\text { a person working } \\
\text { for } 40 \text { years could } \\
\text { already buy a 2- } \\
\text { room apartment. } \\
\text { EVPs were } \\
\text { tradable. } \\
\text { Most privatizers } \\
\text { could buy their } \\
\text { units just for their } \\
\text { EVPs with no } \\
\text { other payment. }\end{array}$ \\
\hline
\end{tabular}




\begin{tabular}{|c|c|c|c|c|}
\hline \multicolumn{5}{|l|}{ Hungary } \\
\hline $\begin{array}{l}\text { Since } 1993 \text {. } \\
\text { About } 80 \% \text { of } \\
\text { the public stock } \\
\text { was privatized } \\
\text { by } 2003 \text {. } \\
\text { Prior to the } \\
\text { privatization } \\
23 \% \text { of the } \\
\text { rental units } \\
\text { were public. }\end{array}$ & $\begin{array}{l}\text { Sitting } \\
\text { tenants. }\end{array}$ & $\begin{array}{l}10-15 \% \text { of the } \\
\text { market price. }\end{array}$ & $\begin{array}{l}\text { Centrally granted } \\
\text { Right-to-Buy for } \\
\text { sitting tenants. } \\
\text { Although the } \\
\text { discounted price } \\
\text { was very low, the } \\
\text { neediest families } \\
\text { with low incomes } \\
\text { and social status } \\
\text { were not } \\
\text { financially assisted } \\
\text { to buy the } \\
\text { property. }\end{array}$ & $\begin{array}{l}\text { Private housing } \\
\text { already since } 1983 \\
\text { had similar } \\
\text { conditions for } \\
\text { public financial } \\
\text { assistance as other } \\
\text { tenure forms. As a } \\
\text { result, the private } \\
\text { ownership became } \\
\text { more popular than } \\
\text { other tenure } \\
\text { forms. } \\
\text { Consequently, the } \\
\text { importance of } \\
\text { public rental } \\
\text { sector decreased } \\
\text { even before } \\
\text { privatization. }\end{array}$ \\
\hline \multicolumn{5}{|l|}{ Latvia } \\
\hline $\begin{array}{l}\text { Since } 1995, \\
\text { peak around the } \\
\text { year } 2000 . \\
\text { About } 55 \% \text { of } \\
\text { the public } \\
\text { housing stock } \\
\text { was privatized } \\
\text { until } 2000 . \\
\text { Prior to } \\
\text { privatization, } \\
70 \% \text { of the } \\
\text { rental units } \\
\text { were public. }\end{array}$ & $\begin{array}{l}\text { Sitting } \\
\text { tenants. }\end{array}$ & $\begin{array}{l}\text { Compensation } \\
\text { vouchers } \\
\text { distributed } \\
\text { according to the } \\
\text { length of } \\
\text { residency/exile } \\
\text { in Latvia during } \\
\text { the period } \\
\text { 1945-1992. }\end{array}$ & $\begin{array}{l}\text { The Central } \\
\text { Housing } \\
\text { Privatization } \\
\text { Commission was } \\
\text { generally } \\
\text { responsible for the } \\
\text { privatization } \\
\text { process although } \\
\text { local governments } \\
\text { assisted it by } \\
\text { appointing its } \\
\text { commissions for } \\
\text { the dwellings } \\
\text { owned by } \\
\text { municipalities. }\end{array}$ & $\begin{array}{l}\text { One voucher } \\
\text { equals to } 0.5 \mathrm{~m}^{2} \text { of } \\
\text { the residential } \\
\text { space. } \\
\text {. Vouchers were } \\
\text { tradable. }\end{array}$ \\
\hline \multicolumn{5}{|l|}{ Lithuania } \\
\hline $\begin{array}{l}\text { 1991-1995. } \\
\text { By } 1995,95 \% \\
\text { of public } \\
\text { housing flats } \\
\text { were privatized. } \\
\text { Fast and } \\
\text { extensive } \\
\text { privatization } \\
\text { even in } \\
\text { comparison } \\
\text { with Estonia } \\
\text { and Latvia. }\end{array}$ & $\begin{array}{l}\text { Sitting } \\
\text { tenants. }\end{array}$ & $\begin{array}{l}\text { Privatization } \\
\text { vouchers } \\
\text { (Investicnis } \\
\text { Cekis, IC) for } \\
\text { residents } \\
\text { distributed } \\
\text { according to the } \\
\text { age of the } \\
\text { recipient. } \\
\text { - Price was set } \\
\text { according to the } \\
\text { construction } \\
\text { characteristics, } \\
\text { location etc. }\end{array}$ & $\begin{array}{l}\text { The privatization } \\
\text { process prepared } \\
\text { by the central } \\
\text { government } \\
\text { encouraged } \\
\text { extremely fast } \\
\text { privatization due } \\
\text { to simple } \\
\text { administrability. } \\
\text { Local } \\
\text { commissions set } \\
\text { the price of } \\
\text { dwellings but had } \\
\text { no incentive to } \\
\text { hinder the process. }\end{array}$ & $\begin{array}{l}\text { - Trading ICs was } \\
\text { not allowed. } \\
\text { - Up to } 80 \% \text { of the } \\
\text { selling price could } \\
\text { be covered by ICs; } \\
\text { rest had to be paid } \\
\text { in cash. } \\
\text { - Signatures of all } \\
\text { the family } \\
\text { members in the } \\
\text { unit and enough } \\
\text { ICs and cash } \\
\text { sufficed to carry } \\
\text { out the } \\
\text { privatization. }\end{array}$ \\
\hline
\end{tabular}




\begin{tabular}{|c|c|c|c|c|}
\hline \multicolumn{5}{|l|}{ Poland } \\
\hline $\begin{array}{l}\text { Since } 1994 . \\
\text { Most of the } \\
\text { privatization } \\
\text { took place } \\
\text { before } 2002 \text {. } \\
\text { Prior to the } \\
\text { privatization } \\
35 \% \text { of the } \\
\text { rental units } \\
\text { were public, } \\
25 \% \text { were } \\
\text { housing } \\
\text { cooperatives. }\end{array}$ & $\begin{array}{l}\text { Sitting } \\
\text { tenants. } \\
\text { Housing } \\
\text { coopera- } \\
\text { tives. }\end{array}$ & $\begin{array}{l}\text { Discount of up } \\
\text { to } 95 \% \text { of the } \\
\text { market value. }\end{array}$ & $\begin{array}{l}\text { Municipalities } \\
\text { decided about the } \\
\text { privatization scale } \\
\text { and terms of most } \\
\text { public dwellings. } \\
\text { - Right-to-Buy only } \\
\text { for tenants in } \\
\text { cooperative } \\
\text { housing. }\end{array}$ & $\begin{array}{l}\text { Majority } \\
\text { privatized to } \\
\text { tenants or coop } \\
\text { members. } \\
\text { Other investors } \\
\text { could privatize } \\
\text { under centrally } \\
\text { specified } \\
\text { conditions, but } \\
\text { municipalities } \\
\text { chose the } \\
\text { dwellings to be } \\
\text { privatized. } \\
\text { April } 2001, \text { co- } \\
\text { operative titles } \\
\text { holders given } \\
\text { right to transform } \\
\text { their existing } \\
\text { tenures into } \\
\text { ownership } \\
\end{array}$ \\
\hline \multicolumn{5}{|l|}{ Romania } \\
\hline $\begin{array}{l}\text { 1990s. } \\
\text { Public stock } \\
\text { almost } \\
\text { completely } \\
\text { privatized by } \\
1999 . \\
\text { - Prior } \\
\text { privatization } \\
75 \% \text { of } \\
\text { homeowners. }\end{array}$ & $\begin{array}{l}\text { Sitting } \\
\text { tenants. }\end{array}$ & $\begin{array}{l}\text { Public financial } \\
\text { assistance: } 25- \\
\text { year loan with } \\
4 \% \text { interest rate. } \\
\text { - Rather } \\
\text { "symbolic } \\
\text { price" } \\
\text { depending on } \\
\text { the construction } \\
\text { year. } \\
\end{array}$ & $\begin{array}{l}\text { Entitled privatizers } \\
\text { as well as contract } \\
\text { conditions } \\
\text { specified centrally. }\end{array}$ & $\begin{array}{l}\text { Privatization } \\
\text { processed by } \\
\text { specialized } \\
\text { agencies. } \\
\text { Dwelling cannot } \\
\text { be resold before } \\
\text { the mortgage has } \\
\text { been repaid. }\end{array}$ \\
\hline \multicolumn{5}{|l|}{ Slovakia } \\
\hline $\begin{array}{l}\text { 1993-2008. } \\
\text { Municipalities } \\
\text { were obliged to } \\
\text { privatize a } \\
\text { dwelling within } \\
\text { two years if } \\
\text { more than a } \\
\text { half of its } \\
\text { tenants agreed. } \\
\text { Prior to the } \\
\text { privatization } \\
25 \% \text { of the } \\
\text { rental units } \\
\text { were public, } \\
20 \% \text { were } \\
\text { housing } \\
\text { cooperatives. }\end{array}$ & $\begin{array}{l}\text { Sitting } \\
\text { tenants. } \\
\text { Housing } \\
\text { coopera- } \\
\text { tives. }\end{array}$ & $\begin{array}{l}\text { Price derived } \\
\text { from a } \\
\text { comparable unit } \\
\text { depending on } \\
\text { the construction } \\
\text { year. } \\
\text { Discounts } \\
\text { between } 30 \text { and } \\
80 \% \text {. }\end{array}$ & $\begin{array}{l}\text { Entitled privatizers } \\
\text { as well as contract } \\
\text { conditions } \\
\text { specified centrally. }\end{array}$ & $\begin{array}{l}\text { Free-of-charge } \\
\text { transfer to the full } \\
\text { ownership of } \\
\text { cooperative } \\
\text { members. } \\
\text { Centrally } \\
\text { specified } \\
\text { conditions for } \\
\text { selling restituted } \\
\text { property to the } \\
\text { siting tenants. }\end{array}$ \\
\hline
\end{tabular}




\begin{tabular}{|c|c|c|c|c|}
\hline \multicolumn{5}{|l|}{ Slovenia } \\
\hline $\begin{array}{l}1991-1993 . \\
\text { Prior to the } \\
\text { privatization } \\
33 \% \text { of the } \\
\text { rental units } \\
\text { were public. }\end{array}$ & - Sitting tenants. & $\begin{array}{l}\text { Discount } \\
\text { over } 30 \% \text {. } \\
\text { If payment } \\
\text { occurred in } \\
60 \text { days, the } \\
\text { discount } \\
\text { increased to } \\
60 \% \text {. }\end{array}$ & $\begin{array}{l}\text { Entitled } \\
\text { privatizers as } \\
\text { well as contract } \\
\text { conditions } \\
\text { specified } \\
\text { centrally. }\end{array}$ & $\begin{array}{l}\text { Centrally specified } \\
\text { conditions for selling } \\
\text { restituted property to } \\
\text { the siting tenants }\end{array}$ \\
\hline \multicolumn{5}{|c|}{ Western European Countries } \\
\hline \multicolumn{5}{|l|}{ Great Britain } \\
\hline $\begin{array}{l}1980 \text { Housing } \\
\text { Act. } \\
\text { One quarter of } \\
\text { the public } \\
\text { housing } \\
\text { privatized } \\
\text { between } 1980 \\
\text { and } 1987 .\end{array}$ & $\begin{array}{l}\text { Mainly sitting } \\
\text { tenants. } \\
\text { All tenants } \\
\text { renting a } \\
\text { separate } \\
\text { housing unit } \\
\text { centrally } \\
\text { granted the } \\
\text { Right-to-Buy } \\
\text { after three } \\
\text { years of } \\
\text { residence. } \\
\text { Later also } \\
\text { housing } \\
\text { associations. }\end{array}$ & $\begin{array}{l}\text { Discount } \\
\text { 30-70\% on } \\
\text { the } \\
\text { estimated } \\
\text { market } \\
\text { price. } \\
\text { Publicly } \\
\text { provided } \\
\text { loans up to } \\
100 \% \text { of the } \\
\text { final price. }\end{array}$ & $\begin{array}{l}\text { Entitled } \\
\text { privatizers as } \\
\text { well as contract } \\
\text { conditions } \\
\text { specified by the } \\
\text { central } \\
\text { government. }\end{array}$ & $\begin{array}{l}\text { - Ideological } \\
\text { (Thatcherism) as well } \\
\text { as practical reasons } \\
\text { played a role. } \\
\text { - As privatization itself } \\
\text { was costly (financial } \\
\text { assistance and tax } \\
\text { reliefs for } \\
\text { privatizers), ideology } \\
\text { is seen as the main } \\
\text { reason. } \\
\text { - Resale within first } 5 \\
\text { years was subject to } \\
\text { capital gain tax. }\end{array}$ \\
\hline \multicolumn{5}{|l|}{ Italy } \\
\hline $\begin{array}{l}\text { Begun in } 1993 \\
\text { and culminated } \\
\text { in } 1999 .\end{array}$ & $\begin{array}{l}\text { Sitting tenants. } \\
\text { Initially } \\
\text { employees of } \\
\text { the privatized } \\
\text { entities. }\end{array}$ & $\begin{array}{l}\text { - Low rates in } \\
\text { comparison } \\
\text { to the } \\
\text { market } \\
\text { price. } \\
\text { - Financial } \\
\text { assistance to } \\
\text { privatizers } \\
\text { in form of } \\
\text { credit } \\
\text { facilitations } \\
\text { and tax } \\
\text { reliefs. } \\
\end{array}$ & $\begin{array}{l}\text { Mainly the } \\
\text { central } \\
\text { government. } \\
\text { In recent years } \\
\text { also at the } \\
\text { municipality } \\
\text { level. }\end{array}$ & $\begin{array}{l}\text { A policy to build and } \\
\text { privatize social } \\
\text { housing to low- } \\
\text { income families was } \\
\text { adopted already in } \\
\text { 1949, but the extent } \\
\text { of privatization } \\
\text { resulting from this } \\
\text { initiative was much } \\
\text { smaller than that one } \\
\text { following in 1990s. }\end{array}$ \\
\hline \multicolumn{5}{|l|}{ Sweden } \\
\hline $\begin{array}{l}\text { Since } 1969 \text { the } \\
\text { cooperative } \\
\text { "tenant- } \\
\text { owners" } \\
\text { gained the } \\
\text { right to freely } \\
\text { sell their } \\
\text { dwelling. } \\
\text { - Privatization } \\
\text { of public } \\
\text { housing since } \\
\text { 1981. }\end{array}$ & $\begin{array}{l}\text { Members of } \\
\text { cooperatives. } \\
\text { Sitting tenants } \\
\text { in public } \\
\text { housing. }\end{array}$ & $\begin{array}{l}\text { For } \\
\text { cooperative } \\
\text { members } \\
\text { the legal } \\
\text { status } \\
\text { changed for } \\
\text { free. }\end{array}$ & $\begin{array}{l}\text { The right to sell } \\
\text { coop dwellings } \\
\text { was given by } \\
\text { country-level } \\
\text { legislation. } \\
\text { - Municipalities } \\
\text { were later } \\
\text { entitled to } \\
\text { privatize public } \\
\text { housing. }\end{array}$ & $\begin{array}{l}\text { Social Democrats in } \\
\text { connection with } \\
\text { Municipality Housing } \\
\text { Companies } \\
\text { eventually blocked } \\
\text { direct privatization of } \\
\text { public dwellings. }\end{array}$ \\
\hline
\end{tabular}




\begin{tabular}{|c|c|c|c|c|}
\hline West Germany & & & & \\
\hline $\begin{array}{l}\text { Since late } \\
\text { 1990s. }\end{array}$ & $\begin{array}{l}\text { Mainly } \\
\text { institutional } \\
\text { investors } \\
\text { buying } \\
\text { substantial } \\
\text { bundles of } \\
\text { dwellings. } \\
\text { - Cooperative } \\
\text { members. } \\
\text { - Sitting tenants. }\end{array}$ & $\begin{array}{l}\text { Federal } \\
\text { sales to } \\
\text { institutional } \\
\text { investors for } \\
\text { extremely } \\
\text { low prices. }\end{array}$ & $\begin{array}{l}\text { Federal } \\
\text { government. } \\
\text { - Municipalities. }\end{array}$ & $\begin{array}{l}\text { Central government } \\
\text { privatized housing } \\
\text { owned by state-held } \\
\text { companies, such as } \\
\text { the railways, to } \\
\text { institutional investors. } \\
\text { - Municipalities also } \\
\text { sold mainly to } \\
\text { institutional investors, } \\
\text { although federal } \\
\text { government } \\
\text { recommended direct } \\
\text { privatization to } \\
\text { tenants. } \\
\text { No centrally reported } \\
\text { data on individual } \\
\text { sales. }\end{array}$ \\
\hline
\end{tabular}

Note: Information sources for individual transition countries: Czech Republic: Lux (2003); Struyk (1996); Grabmüllerová (2005). Estonia: Kask, Klettenberg, and Lembit (2005); Kursis (1999); Lux (2003); Struyk (1996). Hungary: Hegedüs et al. (1996); Struyk (1996); Tosics (1987). Latvia: Kursis (1999); Osa (2005); Tsenkova and Turner (2004). Lithuania: Housing, Urbanization, and Development Fund (2005); Jurgatyte (2002); Kursis (1999); Milstead and Miles (2011). Poland: Lis and Zwierzchlewski (2015); Lux (2003); Skiba (2005); Struyk (1996); Zawislak (2002). Romania: Dübel et al. (2006); Lux (2003); Palacin and Shelburne (2005). Slovakia: Lux (2003); Struyk (1996); Zapletalova, Antalikova, and Smatanova (2003). Slovenia: Mandic and Clapham (1996); Sendi (1995); Struyk (1996). 
Table 2. Housing Tenure Structure (Proportions), continues on next page

\begin{tabular}{|c|c|c|c|c|c|}
\hline & \multicolumn{2}{|c|}{ Privatized } & \multirow{2}{*}{$\begin{array}{l}\text { Test 2006-2010 } \\
\text { difference }\end{array}$} & \multicolumn{2}{|c|}{ Bought/built/inherited } \\
\hline & 2006 & 2010 & & 2006 & 2010 \\
\hline & \multicolumn{5}{|c|}{ Central and Eastern Europe } \\
\hline Bulgaria & 5.22 & 0.11 & $-7 * * *$ & 78.03 & 90.82 \\
\hline Czech Republic & 4.90 & 4.68 & -0.2 & 55.40 & 63.05 \\
\hline East Germany & NA & 8.36 & & NA & 25.37 \\
\hline Hungary & 1.31 & 0.68 & -1 & 85.27 & 83.50 \\
\hline Poland & 6.61 & 11.36 & $4 * * *$ & 58.43 & 66.06 \\
\hline Romania & 8.63 & 8.53 & -0.3 & 86.55 & 86.19 \\
\hline Slovakia & 21.58 & 2.26 & $-10 * * *$ & 71.83 & 75.64 \\
\hline \multirow[t]{2}{*}{ Slovenia } & 3.81 & 8.70 & $5 * * *$ & 82.77 & 78.40 \\
\hline & \multicolumn{5}{|c|}{ Former Soviet Union (incl. Baltics) } \\
\hline Armenia & 30.96 & 32.46 & 0.03 & 58.52 & 60.40 \\
\hline Azerbaijan & 23.69 & 25.96 & 1 & 64.76 & 66.43 \\
\hline Belarus & 36.04 & 37.78 & -0.4 & 44.44 & 44.99 \\
\hline Estonia & 34.48 & 37.55 & 1 & 47.08 & 47.76 \\
\hline Georgia & 24.30 & 31.89 & $3 * *$ & 69.10 & 60.72 \\
\hline Kazakhstan & 27.60 & 36.39 & $4 * * *$ & 65.20 & 54.54 \\
\hline Kyrgyzstan & 16.70 & 17.69 & 0.5 & 77.40 & 75.59 \\
\hline Latvia & 37.80 & 50.57 & $5 * * *$ & 37.30 & 19.77 \\
\hline Lithuania & 20.90 & 29.64 & $3 * *$ & 64.20 & 59.60 \\
\hline Moldova & 16.82 & 17.92 & 0.6 & 77.18 & 73.60 \\
\hline Russia & 47.30 & 61.69 & $5 * * *$ & 39.70 & 22.91 \\
\hline Tajikistan & 18.00 & 32.30 & $7 * * *$ & 78.70 & 62.75 \\
\hline Ukraine & 32.90 & 35.95 & 1 & 60.90 & 57.17 \\
\hline \multirow[t]{2}{*}{ Uzbekistan } & 21.00 & 13.24 & $-5^{* * *}$ & 75.90 & 85.43 \\
\hline & \multicolumn{5}{|c|}{ Balkans } \\
\hline Albania & 24.80 & 32.32 & $4 * * *$ & 67.70 & 60.09 \\
\hline Bosnia and Herzegovina & 7.69 & 5.21 & $-2 *$ & 80.41 & 84.82 \\
\hline Croatia & 4.90 & 5.58 & 0.7 & 82.48 & 83.96 \\
\hline Kosovo & NA & 2.93 & & & 92.12 \\
\hline Macedonia & 5.42 & 9.62 & $4 * * *$ & 87.25 & 82.54 \\
\hline Montenegro & 12.95 & 3.06 & $-8 * * *$ & 68.20 & 82.43 \\
\hline \multirow[t]{2}{*}{ Serbia } & 9.91 & 8.16 & -1 & 76.44 & 83.34 \\
\hline & \multicolumn{5}{|c|}{ Western Europe } \\
\hline France & NA & 0.00 & & NA & 74.30 \\
\hline Great Britain & NA & 4.04 & & NA & 57.13 \\
\hline Italy & NA & 25.84 & & NA & 51.20 \\
\hline Sweden & NA & 15.48 & & NA & 53.78 \\
\hline West Germany & NA & 11.27 & & NA & 36.80 \\
\hline
\end{tabular}


Table 2. continued

\begin{tabular}{|c|c|c|c|c|c|c|}
\hline & \multicolumn{2}{|c|}{ Rented } & \multicolumn{2}{|c|}{ Cooperative } & \multicolumn{2}{|c|}{ Observations } \\
\hline & 2006 & 2010 & 2006 & 2010 & 2006 & 2010 \\
\hline & \multicolumn{6}{|c|}{ Central and Eastern Europe } \\
\hline Bulgaria & 15.55 & 8.23 & 1.20 & 0.84 & 997 & 948 \\
\hline Czech Republic & 28.80 & 20.02 & 10.90 & 12.25 & 1,000 & 1,004 \\
\hline East Germany & NA & 66.27 & NA & 0.00 & NA & 335 \\
\hline Hungary & 11.71 & 10.74 & 1.72 & 5.08 & 991 & 1,024 \\
\hline Poland & 20.63 & 10.16 & 14.33 & 12.42 & 984 & 1,594 \\
\hline Romania & 3.82 & 4.70 & 1.00 & 0.58 & 996 & 1,043 \\
\hline Slovakia & 5.59 & 11.41 & 1.00 & 10.69 & 1,001 & 973 \\
\hline \multirow[t]{2}{*}{ Slovenia } & 12.22 & 12.00 & 1.20 & 0.90 & 998 & 1,000 \\
\hline & \multicolumn{6}{|c|}{ Former Soviet Union (incl. Baltics) } \\
\hline Armenia & 4.21 & 5.46 & 6.31 & 1.68 & 998 & 952 \\
\hline Azerbaijan & 10.64 & 6.39 & 0.90 & 1.22 & 996 & 986 \\
\hline Belarus & 15.62 & 12.27 & 3.90 & 4.95 & 999 & 929 \\
\hline Estonia & 16.83 & 12.96 & 1.61 & 1.73 & 992 & 980 \\
\hline Georgia & 4.80 & 5.39 & 1.80 & 2.01 & 1,000 & 947 \\
\hline Kazakhstan & 6.20 & 8.37 & 1.00 & 0.71 & 1,000 & 992 \\
\hline Kyrgyzstan & 4.80 & 6.42 & 1.10 & 0.30 & 1,000 & 1,012 \\
\hline Latvia & 24.70 & 28.22 & 0.20 & 1.44 & 1,000 & 971 \\
\hline Lithuania & 10.40 & 8.01 & 4.50 & 2.74 & 1,000 & 911 \\
\hline Moldova & 5.41 & 5.20 & 0.60 & 3.28 & 999 & 1,038 \\
\hline Russia & 11.50 & 11.12 & 1.50 & 4.29 & 1,000 & 1,493 \\
\hline Tajikistan & 2.90 & 3.10 & 0.40 & 1.86 & 1,000 & 969 \\
\hline Ukraine & 4.10 & 5.44 & 2.10 & 1.44 & 1,000 & 1,527 \\
\hline \multirow[t]{2}{*}{ Uzbekistan } & 2.70 & 1.27 & 0.40 & 0.07 & 1,000 & 1,496 \\
\hline & \multicolumn{6}{|c|}{ Balkans } \\
\hline Albania & 6.10 & 7.39 & 1.40 & 0.19 & 1,000 & 1,055 \\
\hline $\begin{array}{l}\text { Bosnia and } \\
\text { Herzegovina }\end{array}$ & 9.95 & 9.22 & 1.95 & 0.74 & 975 & 1,074 \\
\hline Croatia & 10.51 & 9.56 & 2.10 & 0.90 & 999 & 1,004 \\
\hline Kosovo & & 4.49 & & 0.46 & & 1,091 \\
\hline Macedonia & 6.02 & 3.83 & 1.31 & 4.01 & 996 & 1,071 \\
\hline Montenegro & 16.11 & 13.92 & 2.75 & 0.59 & 981 & 1,013 \\
\hline \multirow[t]{2}{*}{ Serbia } & 12.54 & 8.36 & 1.11 & 0.13 & 989 & 1,519 \\
\hline & \multicolumn{6}{|c|}{ Western Europe } \\
\hline France & NA & 25.70 & NA & 0.00 & NA & 1,000 \\
\hline Great Britain & NA & 38.69 & NA & 0.13 & NA & 1,486 \\
\hline Italy & NA & 22.19 & NA & 0.77 & NA & 1,041 \\
\hline Sweden & NA & 30.38 & NA & 0.35 & NA & 846 \\
\hline West Germany & NA & 51.78 & NA & NA & NA & 701 \\
\hline
\end{tabular}

